\title{
A AVALIAÇÃO DA ARTE NO ESPORTE: ESTUDO SOBRE COMPONENTE ARTíSTICO NOS ESPORTES OLÍMPICOS
}

\author{
Mateus Henrique de Oliveira*, Eliana de Toledo
}

\section{Resumo}

Específicas práticas esportivas presentes no programa olímpico atual contam com Componentes Artísticos, que são formas de avaliação de desempenho com base em conceitos relacionados à arte, e avaliados juntamente do desempenho técnico da realização de elementos de dificuldade. O objetivo do presente trabalho é o de analisar como tais componentes são descritos a fim de melhor compreendê-los.

\section{Palavras-chave: \\ Componente artístico, Esporte olímpico, Esporte e arte}

\section{Introdução}

Belenkaya (2016) destaca que a preparação esportiva engloba 4 áreas específicas: física, técnica, tática e psicológica. Mas em algumas práticas esportivas além dessas serem obrigatórias, existem algumas outras áreas tão importantes quanto para o sucesso desportivo, como a preparação artística, musical e coreográfica, presentes nos esportes com orientação artística/estética. De acordo com Chiat e Ying (2012), as habilidades acrobáticas realizadas pelos atletas nessas modalidades, sem dúvida, contribuem com o principal fator vencedor, mas a correlação entre coreografia e música afeta indiretamente toda a performance nos esportes considerados artísticos. Dessa forma, o objetivo principal do trabalho é o de identificar as similaridades e diferenças dos componentes artísticos presentes nas modalidades olímpicas em que está presente - Ginástica Artística, Ginástica Rítmica, Nado Artístico e Patinação no Gelo -, a fim de compreender melhor o que é e como é avaliado tal componente.

\section{Resultados e Discussão}

Tabela 1: Comparação entre aspectos gerais das modalidades

\begin{tabular}{|c|c|c|c|}
\hline $\begin{array}{l}\text { Ginástica } \\
\text { Artística }\end{array}$ & $\begin{array}{c}\text { Ginástica } \\
\text { Rítmica }\end{array}$ & $\begin{array}{c}\text { Nado } \\
\text { Artístico }\end{array}$ & $\begin{array}{c}\text { Patinação } \\
\text { no Gelo }\end{array}$ \\
\hline \multicolumn{4}{|c|}{ Formas de julgamento do componente } \\
\hline $\begin{array}{c}5 \text { árbitros, } \\
\text { junto da } \\
\text { Nota de } \\
\text { execução }\end{array}$ & $\begin{array}{c}2 \text { árbitros } \\
\text { específicos, } \\
\text { na Nota de } \\
\text { execução }\end{array}$ & $\begin{array}{l}5 \text { árbitros, } \\
\text { Painel de } \\
\text { Impressões } \\
\text { Artísticas }\end{array}$ & $\begin{array}{c}9 \text { árbitros, } \\
\text { compõem } \\
\text { Nota de } \\
\text { Apresentaçã } \\
0\end{array}$ \\
\hline \multicolumn{4}{|c|}{ Utilização de música } \\
\hline $\begin{array}{c}\text { Apenas } \\
\text { instrumen } \\
\text { tais }\end{array}$ & $\begin{array}{c}\text { Música } \\
\text { cantada } \\
\text { permitida } \\
\text { em metade } \\
\text { das séries }\end{array}$ & $\begin{array}{l}\text { Todo tipo } \\
\text { de música } \\
\text { permitido }\end{array}$ & $\begin{array}{l}\text { Todo tipo de } \\
\text { música } \\
\text { permitido }\end{array}$ \\
\hline \multicolumn{4}{|c|}{ Idade mínima para competição em modalidade adulta } \\
\hline 16 anos & 16 anos & 15 anos & 15 anos \\
\hline \multicolumn{4}{|c|}{ Tempo total das séries } \\
\hline $\begin{array}{c}\text { 1:30 para } \\
\text { Trave e } \\
\text { Solo }\end{array}$ & $\begin{array}{c}1: 30 \text { para } \\
\text { individuais } \\
\text { e } 2: 30 \text { para } \\
\text { conjunto }\end{array}$ & $\begin{array}{c}\text { Entre } 2 \text { e } 4 \\
\text { minutos, } \\
\text { Solo/Dueto } \\
\text { e Equipe }\end{array}$ & $\begin{array}{c}\text { Entre } 2: 40 \text { e } \\
4 \text { minutos, } \\
\text { Individuais e } \\
\text { Pares }\end{array}$ \\
\hline
\end{tabular}

- Patinação é a única a contemplar uma modalidade exclusivamente masculina com a presença do componente artístico;

- Ginástica Artística é a única das modalidades que avalia o componente artístico sem utilização de acompanhamento musical (Trave de Equilíbrio);

- Ginástica Rítmica é a única das modalidades a não contemplar participação masculina; Atleta deve realizar 4 diferentes séries com distintos ritmos musicais;

- Nas Ginásticas, os atletas recebem descontos de execução de acordo com as falhas consideradas artísticas; Nas outras modalidades o atleta recebe uma nota cheia, de acordo com o seu desempenho nesse quesito.

- Nas Ginásticas o tempo de séries individuais é menor do que $o$ das outras modalidades.

- Em todas as modalidades existem penalidades por não utilização de todo o espaço de competição, e são valorizados aspectos técnicos como relação músicamovimento, dinamismo, expressividade e confiança.

\section{Conclusões}

De modo geral, fica evidente que o componente artístico está fortemente presente nas modalidades olímpicas, e atrelado com o desempenho esportivo, tornando-o um fator essencial para a prática desses esportes. Ainda que avaliado de diferentes formas, seja através de decréscimo de notas envoltos em outros componentes ou com uma nota específica para sí, o componente artístico se mostra importante para tais práticas, sendo em algumas delas mais valorizado do que a dificuldade ou execução dos elementos característicos de cada modalidade apresentados pelos atletas.

\section{Agradecimentos}

Agradecimentos a minha orientadora Eliana de Toledo, ao Laboratório de Pesquisas e Experiências em Ginástica - LAPEGI, a Pró-Reitoria de Graduação $P R P / U N I C A M P$ e ao $C n P Q$.

BELENKAYA, Irina. Musical training of coaches in aesthetic-oriented sports Slobozhanskyi herald of science and sport, n. 3 (53), p. 5-8, 2016

CHIAT, Loo Fung; YING, Loo Fung. Importance of music learning and musicality in rhythmic gymnastics. Procedia-Social and Behavioral Sciences, v. 46, p. $3202-3208,2012$ 